\title{
Based on the Theory of Reliability High Piers Short Towers Cable-Stayed Bridge Characteristic Parameter Analysis
}

\author{
Song Jun ${ }^{1}$, Zhou Jianting ${ }^{1}$, Yang Jianxi ${ }^{1} \&$ Chen Zengshun ${ }^{1}$ \\ ${ }^{1}$ School of Civil Engineering \& Architecture, Chongqing Jiaotong University, Chongqing, China \\ Correspondence: Song Jun, School of Civil Engineering \& Architecture, Chongqing Jiaotong University, \\ Chongqing 400074, China. E-mail: songjun198298@163.com
}

Received: December 13, 2012

doi:10.5539/mas.v7n4p41
Accepted: March 5, 2013 Online Published: March 13, 2013

URL: http://dx.doi.org/10.5539/mas.v7n4p41

\begin{abstract}
In view of high pier extradosed cable-stayed bridge structure characteristics, Yunnan Nanpangjiang River Bridge is taken as an example. This paper studies the influence of parameter change on the structure of the main girder by adjusting the girder height, cable tower height, bending stiffness and the cable tower pier stiffness. It can help us understand mechanical properties of the structure so as to estimate safety evaluation when the structure parameters are changed. Furthermore, it can provide the reference for economic and reasonable structure form design in the bridge of safety evaluation. It also can evaluate the safety of girder and tower through reliability theory. The result shows that the application of reliability theory is reliable and practical to evaluate the high pier extradosed cable-stayed bridge safety performance.
\end{abstract}

Keywords: low-pylon cable-stayed bridge, reliability, over-height pier, characteristic parameters

\section{Introduction}

Low-pylon cable-stayed bridge named Extradose bridge is put forward by the French engineers Jacques Mathivat in 1988 (Song, Wang, \& Shang, 2011; Lin, Sun, \& Liu, 2005; Ouyang, 2006; Zheng, Huang, \& Zhang, 2003; Zhou, 2005; Yan, 1996). And then it rose and developed in Japan. Though domestic relative research started later but the development is rapid, such as has more than 30 seats short towers cable-stayed bridge which has been built and constructed. The characteristics of short towers cable-stayed bridge is short tower, the focus cable on structures and for high time for the static structure (Housner et al., 1997; Myroll \& Dibiagio, 1994; Andersen, 1994; Curran \& Tilly, 1999). The mechanical behavior depends on the girders, the main tower, main piers and the stiffness of the lasso. But ultra short towers cable-stayed bridge pier stress is more complex, it is necessary to analysis characteristic parameters (Chueng et al., 1997; Lau et al., 1999) and assess safety by the reliability theory.
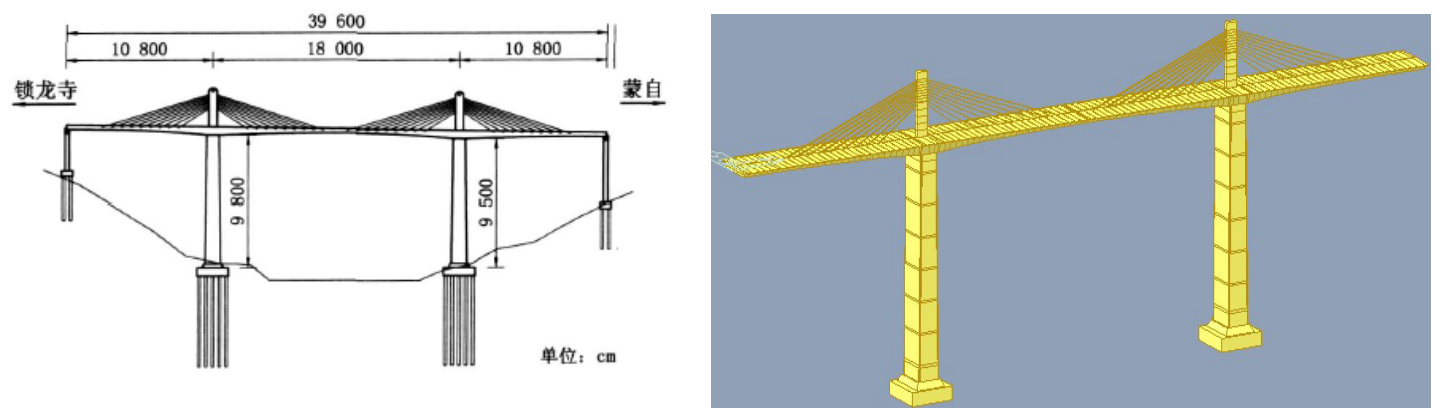

Figure 1. The overall layout and finite element model

Yunnan nanpanjiang bridge is a main $108+180+108$ short towers cable-stayed bridge, for single box girder three room oblique webs cross-section of box girder, beam high by two parabolic change, root beam high $5.8 \mathrm{~m}$, such as high beam at the end of the $3 \mathrm{~m}$. The main tower adopts rectangle solid section plane size $5.5 \mathrm{~m}$ multiply $2.6 \mathrm{~m}$, bridge deck above $29 \mathrm{~m}$ high tower. The whole bridge 4 multiply 9 to lasso with single cable plane double row layout in the central space. Stay-cables tower on anchoring way in the steel strand stay-cables on the tower 
through the cluster steel tube breakthrough (cable saddle) anchoring way, the main structure is welding cluster points wire steel tube. The main pier cross-section of reinforced concrete hollow pier, due to the characteristics of high piers as high as $98 \mathrm{~m}$, in the country has built more than 30 a short towers cable-stayed bridge belongs to the highest pier which it is shown in Table 1. The whole bridge tower pier beam for consolidation system, the bridge is scheduled for completion by the end of 2012 .

Table 1. China has built the extradosed cable-stayed bridge high statistics

\begin{tabular}{ccc}
\hline The Bridges & Span $(\mathrm{m})$ & Pier high $(\mathrm{m})$ \\
\hline Yunnan nanpanjiang bridge & $108+180+108$ & 98 \\
Chongqing jia yue bridge & $145+250+145$ & 88.8 \\
Wuhu changjiang river bridge & $180+312+180$ & 72.2 \\
Lotus hemp creek bridge & $125+230+125$ & 30.492 \\
Liuzhou three river bridge & $100+160+100$ & 24.3 \\
Zhoushan three reef port bridge & $120+210+210+115$ & 20.1 \\
LiShi viaduct & $85+135+85$ & 20 \\
Zhangzhou combat readiness bridge & $80.8+132+80.8$ & 16.5 \\
Small west lake bridge & $81.2+136+81.2$ & 15 \\
Kaifeng Yellow River bridge & $85+6 * 140+85$ & 12 \\
\hline
\end{tabular}

\section{Methodology}

\subsection{Calculation Mode}

In order to analyze the effect of the live following five calculation model to calculate structural contrast: a, according to three span continuous beam calculation, not considering the role of lasso. $b$, the only change main piers stiffness. c, only change inertia. d, girder only change tower (i.e. H stay-cables $\theta$ dip Angle and length L). e, only change lasso sectional area.

$$
\begin{gathered}
\delta f=\frac{\left(f_{\text {continuous beam }}-f_{\text {cable stable bridge }}\right)}{f_{\text {continuous beam }}}, \delta M^{t}=\frac{\left(M_{\text {continuous beam }}^{t}-M_{\text {cable stable bridge }}^{t}\right)}{M_{\text {continuous beam }}^{t}}, \\
\delta M^{b}=\frac{\left(M_{\text {continuous beam }}^{b}-M_{\text {cable stable bridge }}^{b}\right)}{M^{b}{ }_{\text {continuous beam }}}, \\
\delta T=\frac{T_{\text {cable stable bridge }}}{P l},(P l \text { is Live load weight }) \\
\delta f 、 \delta M^{t} 、 \delta M^{\mathrm{b}} 、 \delta T
\end{gathered}
$$

For the main girder respectively across deflection, the tower in the root bending moment, cross bending moment and the effect of cable force.

$$
f_{\text {cable stayed bridge }}, M_{\text {cable stayed bridge }}^{t}, M_{\text {cable stayed bridge }}^{b}, T_{\text {cable stayed bridge }}
$$

Where short stay in the tower bridge cross deflection, the tower across the bending moment, the bending moment and the vertical component of total cable force.

$$
f_{\text {continuous beam }}, M_{\text {continuousbeam }}^{t}, M_{\text {continuous beam }}^{b}
$$

For continuous girder overhead traveling crane respectively the midspan deflection, the pillar top bending moment, the midspan bending moment. 


\subsection{Parameter Analysis Results}

Table 2 . The main pier of flexural rigidity

\begin{tabular}{ccccccccc}
\hline $\begin{array}{c}\text { The rigidity } \\
\text { of pier } \\
\beta 1\end{array}$ & 0.5 & 1 & 1.5 & 2 & 2.5 & 3 & 5 & 10 \\
\hline$\delta f(\%)$ & 29.85 & 29.97 & 30.13 & 31.26 & 31.37 & 32.56 & 33.70 & 35.77 \\
$\delta M^{\mathrm{b}}(\%)$ & 40.60 & 40.12 & 38.69 & 37.30 & 35.42 & 34.77 & 33.61 & 30.27 \\
$\delta M^{t}(\%)$ & 22.99 & 23.21 & 23.39 & 23.40 & 23.45 & 23.57 & 23.98 & 25.20 \\
\hline
\end{tabular}

Notes: $\beta 1$ is the main pier stiffness and real bridge main pier stiffness ratio in the "b" pattern.

Table 3. Main beam flexural stiffness

\begin{tabular}{ccccccccc}
\hline $\begin{array}{c}\text { Beam } \\
\text { rigidity } \\
\beta 2\end{array}$ & 0.5 & 1 & 1.5 & 2 & 2.5 & 3 & 5 & 10 \\
\hline$\delta f(\%)$ & 25.65 & 19.72 & 15.56 & 9.41 & 7.88 & 6.71 & 4.33 & 2.01 \\
$\delta M^{\mathrm{b}}(\%)$ & 28.69 & 20.53 & 17.74 & 13.26 & 9.41 & 7.69 & 5.42 & 1.98 \\
$\delta M^{t}(\%)$ & 44.90 & 37.45 & 29.88 & 22.80 & 18.78 & 12.59 & 8.37 & 3.77 \\
$\delta T(\%)$ & 30.46 & 23.74 & 17.66 & 14.95 & 12.38 & 10.55 & 7.93 & 3.01 \\
\hline
\end{tabular}

Notes: $\beta 2$ is beam rigidity and real bridge girder stiffness ratio of $\mathrm{c}$ model.

Table 4. Pylon height variation

\begin{tabular}{ccccccccc}
\hline $\begin{array}{c}\text { Tower } \\
\mathrm{H} / \mathrm{m}\end{array}$ & 0 & 5 & 10 & 15 & 20 & 25 & 30 & 40 \\
\hline$\delta f(\%)$ & 0.24 & 2.01 & 4.74 & 12.33 & 17.89 & 23.67 & 28.01 & 32.11 \\
$\delta M^{\mathrm{b}}(\%)$ & 0.15 & 1.95 & 7.44 & 13.57 & 20.23 & 23.55 & 28.34 & 33.67 \\
$\delta M^{t}(\%)$ & 0.27 & 2.33 & 9.56 & 23.43 & 33.09 & 45.88 & 53.29 & 55.81 \\
$\delta T(\%)$ & 0 & 1.23 & 5.66 & 15.34 & 23.73 & 30.98 & 34.21 & 39.44 \\
\hline
\end{tabular}

Notes: $\mathrm{H}$ is the tower height, when tower height is zero, Cable is equivalent in vitro prestressed beam.

Table 5. Cable area change

\begin{tabular}{ccccccccc}
\hline Cable area $\beta$ & 0 & 0.1 & 0.2 & 0.4 & 0.5 & 0.75 & 1 & 2 \\
\hline$\delta f(\%)$ & 0 & 4.62 & 6.73 & 10.25 & 15.33 & 24.95 & 32.17 & 45.95 \\
$\delta M^{\mathrm{b}}(\%)$ & 0 & 7.54 & 9.35 & 11.23 & 13.84 & 16.13 & 18.56 & 21.33 \\
$\delta M^{t}(\%)$ & 0 & 9.95 & 11.98 & 15.62 & 17.33 & 20.48 & 24.76 & 35.83 \\
$\delta T(\%)$ & 0 & 2.38 & 4.47 & 7.22 & 11.58 & 15.49 & 17.88 & 25.41
\end{tabular}

Notes: $\beta$ is sectional area of cable and cable section area ratio the "e" model.

\subsection{Analysis of Characteristic Parameters}

$$
\gamma=\frac{\sum_{\mathrm{i}=1}^{\mathrm{n}}\left(\mathrm{E}_{\mathrm{i}} \mathrm{A}_{\mathrm{i}} \sin ^{2} \theta_{\mathrm{i}} / \mathrm{L}_{\mathrm{i}}\right)}{\left(\mathrm{E}_{\mathrm{g}} \mathrm{I}_{\mathrm{g}} \mathrm{E}_{\mathrm{d}} \mathrm{I}_{\mathrm{d}} / \mathrm{L}_{0}^{6}\right)}
$$


$E_{i}, A_{i}, \theta_{i}, L_{i}$ Respectively of stay-cables elastic modulus, area, dip Angle, length; $E_{g}, I_{g}, E_{d}, I_{d}$ Were short towers cable-stayed bridge girder of the elastic modulus, main piers of inertia and the elastic modulus, inertia; $\mathrm{N}$, $\mathrm{L}_{0}$ respectively in the main span cable tower of the number of its Suo Gen cables to the influence of the main girder range, $\mathrm{L}_{0}=\lambda \mathrm{L}$, including $\mathrm{L}$ main span span, and the $\lambda$ main span for edge than. For this bridge $\lambda=$ $108 / 180=0.6$.

With high piers short towers cable-stayed bridge response characteristic parameters main piers stiffness, tower, lasso section area, girders of bending stiffness changes.

The four models of ultra high piers short towers cable-stayed bridge tower the influence of the root bending moment $M_{\text {cable-stayed bridge }}^{t}$ trend.



B-The main pier stiffness, C-Tower height changes, D-Cable cross-sectional area changes, E-Main beam flexural stiffness

Figure 2. Relationship between bending moment and characteristic parameters

From the Figure 2 see $M_{\text {cable-stayed bridge }}^{t}$ value along with the increase of increases, when the $\gamma<40$ when C, D, E mode $M_{\text {cable-stayed bridge }}^{t}$ and $\gamma$ the relevance of the consistent, B mode influence after three of the contrast little influence. Ultra short towers cable-stayed bridge pier characteristic parameters can reflect the pier stiffness, tower, lasso section area, girders of bending stiffness changes on the structure performance impact.

\section{Reuslts}

\subsection{Girders Failure Mode}

Key section caused by excessive moment strength failure (static bending failure)

Function:

$$
\mathrm{Z}_{1}=M_{b}-\left[\pi P_{w}\left(l^{\prime}\right)^{2} / 16+Q L^{2} / 800+3 E I_{x} d / L_{0}^{2}\right]
$$

$\mathrm{M}_{\mathrm{b}}$-Girders resistance moment

$\mathrm{P}_{\mathrm{w}}$-Automobile loading

L'-The elastic supporting beams of the convert length

Q-unbalance loading

L-Bridge span

E-Elastic modulus

$\mathrm{I}_{\mathrm{x}}-$ Section of the girder of inertia

d-Temperature caused by the lasso displacement

$\mathrm{L}_{0}$-Recent stay-cables feet distance to tower

$\mathrm{M}_{\mathrm{b}}, \mathrm{P}_{\mathrm{w}}, \mathrm{L}$, $, \mathrm{Q}, \mathrm{E}, \mathrm{I}_{\mathrm{x}}$, d-Random variables 
Table 6. Main basic variables

\begin{tabular}{llllllll}
\hline variables & $\mathrm{Mb}$ & $\mathrm{Pw}$ & $\mathrm{L}^{\prime}$ & $\mathrm{Q}$ & $\mathrm{E}$ & $\mathrm{I}$ & $\mathrm{d}$ \\
\hline $\begin{array}{l}\text { Distribution } \\
\text { type }\end{array}$ & Normal & Normal & Normal & Normal & $\begin{array}{l}\text { Logarithmic } \\
\text { normal } \\
\text { distribution }\end{array}$ & Normal & Normal \\
$\begin{array}{l}\text { Average value } \\
\begin{array}{l}\text { Coefficient of } \\
\text { variation }\end{array}\end{array}$ & 0.15 & $47 \mathrm{kN}$ & $56 \mathrm{~m}$ & $301 \mathrm{kN}$ & $\begin{array}{l}3 \times 10^{4} \\
(\mathrm{Mpa})\end{array}$ & $18 \mathrm{~m}^{4}$ & $0.02 \mathrm{~m}$ \\
\hline
\end{tabular}

Table 7. Main reliability results

\begin{tabular}{ccccc}
\hline Failure mode & \multicolumn{2}{c}{ Genetic algorithm } & \multicolumn{2}{c}{ JC method } \\
\hline Static bending failure & $\beta$ & $P_{f}$ & $\beta$ & $P_{f}$ \\
& 3.8345 & $1.32 \times 10^{4}$ & 3.9021 & $1.39 \times 10^{4}$ \\
\hline
\end{tabular}

\subsection{The Main Tower Failure Mode}

1) Transverse Buckling

Considering the extradosed cable-stayed bridge, the tower as consolidation and pier top single cantilever column, its critical pressure can use the following formula:

$$
\mathrm{Z}_{2}=\pi^{2} E I / l^{2}-P
$$

On the function of $I$ is considered effect of conversion of variable cross section moment of inertia; $E$ is calculation of elastic modulus; $\mathrm{L}$ is cable force of the distance from the point to the tap root; PVertical pressure. The type of I, E, P are considered as random variables.

2) Along the Bridge to the Strength Failure

Vehicle live load, cable heating, unilateral sunshine will cause the tower lateral displacement, at the same time in the tower root section generates additional bending moment. The additional bending moment in the calculation of equivalent horizontal force is replaced available. Function is the following:

$$
\mathrm{Z}_{3}=\mathrm{M}-\mathrm{PQ}^{\prime} \mathrm{l}^{3} /\left[3 \mathrm{EI}\left(1-\frac{2}{5} \frac{\mathrm{Pl}^{2}}{\mathrm{EI}}\right)\right]-\mathrm{WQ}^{\prime} \mathrm{lh} /\left[3 \mathrm{EI}\left(1-\frac{2}{5} \frac{\mathrm{Pl}^{2}}{\mathrm{EI}}\right)\right]-\mathrm{Q}^{\prime} \mathrm{l}
$$

Where $\mathrm{h}$ is tower to tower root distance of center of gravity; $\mathrm{P}$ is Vertical component; $\mathrm{W}$ is Weight; $\mathrm{M}$ is the tower root section resistance moment, Q' is Total equivalent horizontal force, I, E, P, Q'and M is random variables.

Table 8 . The main tower of basic variables

\begin{tabular}{llllll}
\hline Variable & $\mathrm{I}\left(\mathrm{m}^{4}\right)$ & $\mathrm{E}\left(10^{3} \mathrm{kN} / \mathrm{m}^{2}\right)$ & $\mathrm{P}(\mathrm{kN})$ & $\mathrm{Q}(\mathrm{kN})$ & $\mathrm{M}(\mathrm{kN} \cdot \mathrm{m})$ \\
\hline $\begin{array}{l}\text { Distribution } \\
\text { type }\end{array}$ & $\begin{array}{l}\text { Normal } \\
\text { distribution }\end{array}$ & $\begin{array}{l}\text { Logarithmic } \\
\text { normal } \\
\text { distribution }\end{array}$ & $\begin{array}{l}\text { Normal } \\
\text { distribution }\end{array}$ & $\begin{array}{l}\text { Normal } \\
\text { distribution }\end{array}$ & $\begin{array}{l}\text { Normal } \\
\text { distribution }\end{array}$ \\
$\begin{array}{l}\text { Average } \\
\text { value }\end{array}$ & 15.2 & $3.5 \times 10^{4}$ & $8.7 \times 10^{4}$ & $2.0 \times 10^{4}$ & $2.5 \times 10^{4}$ \\
$\begin{array}{l}\text { Coefficient } \\
\text { of variation }\end{array}$ & 0.1 & 0.08 & 0.1 & 0.15 & 0.15 \\
\hline
\end{tabular}


Table 9. Reliability calculation of main tower

\begin{tabular}{ccccc}
\hline Failure mode & \multicolumn{2}{c}{ Genetic algorithm } & \multicolumn{2}{c}{ JC method } \\
\hline $\begin{array}{c}\text { Transverse } \\
\text { buckling failure }\end{array}$ & 9.605 & $4.332 \times 10^{-15}$ & 9.593 & $4.41 \times 10^{-15}$ \\
$\begin{array}{c}\text { Along the } \\
\text { bridge to the }\end{array}$ & 3.343 & $2.551 \times 10^{-15}$ & 3.405 & $2.605 \times 10^{-15}$ \\
strength failure & & & & \\
\hline
\end{tabular}

\section{Conclusion}

1) High piers short towers cable-stayed bridge structure stress is more reasonable by the characteristic parameters.

2) With high reliability theory to evaluate the main pylon cable-stayed bridge pier short failure mode, the main tower failure mode that the structural behavior failure probability can provide the basis for the safety assessment.

3) Super high pier extradosed cable-stayed bridge stiffness is composed of the rigidity of main beam, the rigidity of pier, tower stiffness and cable stiffness. The biggest influence on structure is girder stiffness, followed by cable and tower, the minimum impact is main pier stiffness.

\section{References}

Andersen, E. Y. (1994). Structural monitoring of the Great Belt East Bridge. Krokeborg J Proceedings of the 3rd Symposium on Strait Crossing. pp.54-62. Rotterdam: Balkema.

Chueng, M. S., Tadros, G. S., \& Brown, T. G. (1997). Field monitoring and research on performance of the Confederation Bridge. Canadian Journal of Civil Engineering, 24(6), 951-962. http://dx.doi.org/10.1139/cjce-24-6-951

Curran, P., \& Tilly, G. (1999). Design and monitoring of the Flintshire Bridge, UK. Structural Engineering International, 3, 225-228. http://dx.doi.org/10.2749/101686699780481970

Housner, G. W., Bergman, L. A., Caughey, T. K., Chassiakos, A. G., Claus, R. O., Masri, S. F., ... Yao, J. T. P. (1997). Structural control: Past, present, and future. Journal of Engineering Mechanics, 123(9), 897-971. http://dx.doi.org/10.1061/(ASCE)0733-9399(1997)123:9(897)

Lau, C. K., Mak, W. P. N., Wong, K. Y., Chan, W. Y. K., \& Man, K. L. D. (1999). Structural health monitoring of three cable-supported bridges in Hong Kong. Chang F K. Structural Health Monitoring 2000. pp.450-460. Pennsylvania: Technomic Publishing Co.

Myroll, F., \& Dibiagio, E. (1994). Instrumentation for monitoring the Skarnsunder Cable-stayed Bridge. Krokeborg J Proceedings of the 3rd Sympo-sium on Strait Crossing. pp. 207-215. Rotterdam: Balkema.

Lin, P. Z., Sun, H. H., \& Liu, F. K. (2005). West Lake of low-pylon cable-stayed bridge research and characteristic parameters. Journal of Highway and Transportation, 22(10), 56-59.

Ouyang, Y. J. (2006). Low tower cable-stayed bridge structure parameter analysis. Steel Structure, 24(4), 38-42.

Song, J., Wang, F. M., \& Shang, J. N. (2011). Super high piers of low tower cable-stayed bridge structural static analysis (in Chinese). East China Highway, 2, 31-34.

Yan, G. M. (1996). On the partially cable-stayed bridge-South Bridge House in Japan, Japan house generation generation of Beiqiao, little Tian Yuan harbor bridge. Foreign Bridges, 1, 47-50

Zheng, Y. F., Huang, Q., \& Zhang, L. Z. (2003). Partial Cable-stayed Bridge Structural Parameter Analysis. Technology of Highway and Transport, 23(6), 60-64.

Zhou, J. T. (2005). Based on reliability theory in the research on the safety evaluation of bridge remote monitoring system. Doctoral dissertation of Chongqing University. 